\title{
Banking consolidation and credit availability for small medium enterprises : evidence from CAMEU countries
}

\author{
Pamphile Mezui-Mbeng \\ Department of Economics- Omar Bongo University, Libreville, Gabon \\ Corresponding author E-mail: pmezuimbeng@gmail.com
}

\begin{abstract}
This article deals with the question whether the process of banking consolidation worsens small medium enterprises (SME) access to credit in Central African Monetary and Economic Union (CAMEU). We utilized cross-sectional data originated from post consolidation banks in CAMEU over the period 1990 to 2010. From a pooled regression in panel data analysis, we find - contrary to public fear-that banking consolidation in CAMEU does not have a significant negative impact on the financing of small medium enterprises. In particular, our results confirm that consolidation process induced changes in banks structure in terms of size and capitalization which positively influence availability of credit for small medium enterprises in the Union. For policy, the need to strengthen the CAMEU banking system becomes fundamentals if the potentials of the bank consolidation exercise will be fully realized.
\end{abstract}

Keywords: Banking consolidation, bank merger, SMEs financing, bank credit, CAMEU.

\section{Introduction}

Deregulation of the banking industry occurred in the 80s resulted in increased competition between banks and their repositioning that resulted in many mergers and acquisitions of small banks by large financial groups [15]. This phenomenon known as banking consolidation has fueled a vast literature. As it usually addresses through the link with bank failures, literature on the impact of bank consolidation on credit availability for small businesses has not been studied enough. However, it is considerable debate as to this process induces effects on banking structure [1]; [13]; [8]. On the theoretical side, according to [15] the nature of banking consolidation affects access of certain enterprises to external resources. In particular, beyond a certain size mergers between financial intermediaries leads to a marked reduction of credit access for small medium enterprises. However, according to [16] when mergers involve institutions of less important size, they can facilitate access to credit of these enterprises. Ultimately, the banking structure impact on how financial intermediaries provide credit, and on enterprises access to credit. Two main arguments are often used to justify this result.

First, for [17] the bank size explains its ability to offer loans to businesses, since it influences the overall cost of supervision of investment projects to be financed. Thus, acquisition of two banks increased size in terms of assets and therefore increases the overall cost of the expertise [11]. On the other hand, we know from the work of [12] that the supply of credit may depend on the banks ability to diversify their portfolios. To this end, the more bank size is, the more it is able to limit agency problems vis-à-vis depositors potentially exposed to default risk problems.

On the empirical side, the work of [20] leads to the conclusion that bank consolidation reduces access to credit for small medium enterprises. The reason is that the expected return on these credits is reduced, because of the high risk they pose to big banks. [10] observes that the previous effect may be temporary. Conversely, [18] and [13] found that bank consolidation leads to an increase in funding for small businesses. In the case of highly concentrated banking systems, [1] and [4] note that it negatively affects the growth rate of credit to small medium enterprises, in rural and urban markets.

Ultimately, it is clear from the theoretical and empirical literature that the impact of bank consolidation on small medium business access to credit depends on characteristics of the studied banking system.

In the case of the Central African Monetary and Economic Union (CAMEU) countries, the banking system has undergone restructuring in the late $90 \mathrm{~s}$, which are manifested by many mergers and acquisitions and bank recapitalization [2]. In addition, banks are characterized by excess liquidity while paradoxically enterprises derive most of their external resources from financial intermediation. The weakness of the Union banking system is due to smallness 
of size, credit rationing and illiquidity that lead to high banking overhead costs. Consequently, the banking system could not effectively support the real sector of the economy with domestic economy at about 9\% of GDP, compared to developed countries of $272 \%$.

In view of the above, the need to engender a banking system that can support the growth and development of real sector stands out prominent as justification of the banking consolidation process in CAMEU. In addition, while there exists an important literature that attempt to evaluate effects of consolidation program on banks lending performance, this topic has never been treated in the CAMEU banking system case. The present paper stands to fill this gap.

In the light of the forgoing, the general objective of this research effort is to assess the response of flows of credit from banking system to consolidation process in CAMEU countries. Specifically, we evaluate the impact of banking consolidation on availability of credit for small medium enterprises. This is intended to provide directions to guide and shape subsequent policy actions towards making the banking sector adequately responsive to the development financing needs of the CAMEU economies.

The rest of the paper is organized as follows. Section 2 presents characteristics of the CAMEU post-restructuring banking system. Section 3 evaluates effects of banking consolidation on CAMEU's small medium enterprises access to credit are evaluated. Finally, section 4 concludes.

\section{An overview of the post-restructuring CAMEU banking system}

Bank restructuring occurred in the late 80's changed the financial sphere of CAMEU economies. Indeed, in 2012 the CAMEU banking system had 43 banks in operation, which must be added to insurance and microfinance companies. The balance sheet restructuring is marked by excess liquidity, credit rationing and high banking concentration.

For the first two characteristics, the CAMEU banks are in a situation of excess liquidity. They have a permanent imbalance between assets and liabilities, and reflect problem of resources allocation. Paradoxically, economic agents face credit rationing to finance their projects. This phenomenon has resulted in a continued decline in credit to the economy in ten years (from 1993 to 2003, they decreased from $78 \%$ of total assets of all banks to 60\%). Over the same period, balance sheets of banks knew a sharp increase from $6.2 \%$ to $21.8 \%$ and the balance of customer transactions from $-8.7 \%$ to $22.1 \%$. This excess liquidity is also confirmed by the sharp decline in refinancing resources, which in 2003 accounted for $0.44 \%$ of their total budgets, against 60.6\% in 1993 [14]. Since 1991, credit to GDP ratio decreases continuously to an average of $12.7 \%$ in 2000 . Finally, we note that the main source of bank profitability consists of investments with the central bank [2]. Overall, the credit crunch is due to uncertainty that affects eligible projects for bank financing, information asymmetry that characterizes the bank-customer relationship and the inability of commercial banks to transform resources in the short-term jobs.

Regarding the banking concentration, CAMEU has been marked by a significant reduction in the number of banks as a result of mergers and acquisitions, direct or indirect, closing, etc. CAMEU banking concentration can be determined from the ratio deposits on loans and market share. For example, in Cameroon $(51 \%$ of total assets of banks in the CAMEU), it is effective with $54 \%$ of deposits and $49 \%$ of the credits of the entire area. Thus, three banks make the bulk of deposits with $63 \%$ of the funds collected.

Bank concentration can also be understood in terms of market share, that means the place occupied by banks in the total assets and then in terms of geographical distribution agencies. Thus, in Cameroon during the year 2003, three banks (Crédit Lyonnais, Société Générale and BICEC) represented slightly more than $50 \%$ of total assets amounting to 1278 billion. Finally, bank concentration may also be assessed in terms of agencies implantation in CAMEU countries. To this end, approximately $95 \%$ of branches are located in the political and economic capital of Gabon, Cameroon and Congo.

Moreover, the CAMEU banking sector is characterized by a lack of financial innovation and internationalization. This is manifested in part by a virtual absence of financial services and a lack of diversification in the euro area banks [6]. In addition, the banking system remains fragmented and elitist, with the exclusion of bank financing of a large segment of the population. Many of the banks in the Union are small in size and unable to compete with the bigger ones. Some of the small banks, apart from being closely held, are plagued by incidence of non-performing loans, capital deficiencies, weak management and poor corporate governance.

\section{Banking consolidation effects on credit for SMEs}

The study aims at determining the direction and magnitudes of effects of consolidation induced changes in the banking industry, on credit availability for small medium enterprises in the CAMEU zone. 


\subsection{Modeling}

Like [9] and [13] we evaluate the impact of bank consolidation on the availability of credit for small medium enterprises in CAMEU, over the period 1990-2010. In particular, we assume that consolidation encourages banks to select their asset portfolio in order to increase the level of seizures. For this purpose, a bank's loan reaction function is assumed to depend on variables size, capitalization, liquidity, return on equity and market share. Then, availability of credit for small medium enterprises can be written:

$$
\mathrm{CE}_{\mathrm{it}}=\alpha_{0}+\beta_{1} \mathrm{ROE}_{\mathrm{it}}+\beta_{2} \mathrm{CAP}_{\mathrm{it}}+\beta_{3} \mathrm{LQ}_{\mathrm{it}}+\beta_{4} \mathrm{PM}_{\mathrm{it}}+\beta_{5} \mathrm{LT}_{\mathrm{it}}+\varepsilon_{\mathrm{it}}
$$

In equation (1), explanatory variables are available as follows:

- Loans to small medium enterprises (CE) represent volume of credit granted exclusively to small medium enterprises by banks;

- Capital (CAP) consists of shareholders' contributions. These are all available bank capital.

- The liquidity (LQ) is the ability of banks to meet their payment obligations in a timely manner. It is determined from the loans to assets ratio. The higher it is, the less the bank has liquidity;

- Market share (PM) refers to the ratio of the share of bank assets in the total assets of the banking system;

- The size (LT) can have an effect on the volume of credit because of the possibility of diversification, the nature of all investment opportunities, the characteristics of the property or access to equity;

- The return on equity (ROE) is a performance indicator as it helps assess the banking situation. It represents the ability of banks to generate profit, depending on the contributions of its shareholders.

\subsection{Econometric approach}

We use a pooled regression in panel data analysis to estimate equation (1). Our data sample covers the period 19902010 and 13 banks involved in the consolidation process in Gabon, Cameroon and Congo (these countries represent $90 \%$ of banking assets in CAMEU). Data are from the Central Bank and from Bank of France.

Econometric approach first performs a test for individual or non-specific effects. If the test is successful, then we will check the nature of the specific effect. Thus, if there is a fixed specific effect, then we are in the presence of a fixed effect model. In any case, if there is a specific random effect, we proceed to estimate a random effects model. The Hausman test allows choosing the appropriate model. In the case where the Hausman test is not conclusive, we proceed to a comparison of the inter-individual and intra-individual variables variation. .

To determine the best model, we use respectively specification tests, errors autocorrelation test, heteroscedasticity test and possibly endogeneity test. The poolability test amounts to testing equality of coefficients of the studied model in the individual dimension. This test involves determining whether it is reasonable to assume that the theoretical model is the same for all banks, or on the contrary if there are specific to each bank.

The Hsiao homogeneity test returns to confronts the null hypothesis $\mathrm{H}_{0}: \mu_{\mathrm{i}}=\mu$, for $\mathrm{i}=1, \ldots, 13$ (presence of common effects) against the alternative hypothesis $\mathrm{H}_{1}: \mu_{\mathrm{i}} \neq \mu_{\mathrm{j}}$ (presence of individual effects ). Fischer statistics concludes the rejection of $\mathrm{H}_{0}$ or not. The rejection of $\mathrm{H}_{0}$ means that there are specific bank individual effects. In this case, a specific constant $\mu_{\mathrm{i}}$ for each bank is introduced in the model (1).

The specification test shows whether the banks specific effects are significantly different. It is therefore to test the heterogeneity hypothesis of banks. We successively use these tests to select a fixed or a random effect model. In addition, we seek the presence or absence of random individual effects, this amounts to achieve compliance testing of variance: $\mathrm{H}_{0}: \sigma_{\alpha}=0$ (no random effects) against $\mathrm{H}_{1}: \sigma_{\alpha} \neq 0$ (random effects).

Finally, the Hausman test determines whether coefficients obtained from the two estimates (fixed effects or random effects) are statistically different. The Wooldridge autocorrelation errors test admits as $\mathrm{H}_{0}$ the intra-individual first order autocorrelation, that means $\mathrm{E}\left(\varepsilon_{\mathrm{t}} \cdot \varepsilon_{\mathrm{s}}\right) \neq 0$ for $\mathrm{t} \neq \mathrm{s}$. If $\mathrm{H}_{0}$ is rejected, then errors are autocorrelated. Finally, for the heteroscedasticity test, we use the Breusch-Pagan test and the Wald test, according to the chosen specification. The Breusch-Pagan procedure purposes a regression in the structural fixed effects model and the recovering of residual. Then residual is squared and regressed on explanatory variables of the structural model. Under the null hypothesis (homoscedasticity), the statistic test follows a chi-2 (k-1), where k represents the number of variables, including constant. Finally, when the model is specified, we proceed to estimation and interpretation of results.

\subsection{Estimation results and analysis}

The previous approach is applied to estimate model (1). All variables have previously been transformed into logarithms. The following results were obtained: 
The homogeneity test results in table 1 shows a Fisher statistic $F(13,42)=309.42$ and Prob $>F=0.000$. Thus, the null hypothesis of no specific effect in model (1) is rejected at the 5\% level. We therefore accept the presence of specific effects in model (1).

The heterogeneity test in table 2 determines whether banks specific effects are significantly different. The result of the Fisher heterogeneity test is as follows: $F(12,37)=3.14$ and Prob $>F=0.0125$. Therefore, we reject $\mathrm{H}_{0}$ and conclude that there are bank specific effects. To this end, the Breusch-Pagan test in table 3 provides the following result: Chi2 (12) = 5.40 and Prob $>$ chi $2=0.0202$. As Prob $>$ chi 2 at $5 \%$, we reject the hypothesis of non specific random effects in the model.

Finally, the Hausman test allows us choosing between a fixed effect model and a random effect model. The following results are obtained: chi2 $(17)=1.53$, Prob $>$ chi $2=0.9340$. Therefore, the Hausman test does not discriminate between a fixed effect model and a random effects model. Table 4 leads us to compare differences of each variable changes. To this end, Table 4 results lead to retain a fixed effects model.

The Wooldridge test found no residuals autocorrelation, since the Fisher statistic F $(12,48)=1.55$ and Prob $>F=0.191$. The residual test of normality due to Shapiro-Wilk in table 5 shows that residuals follow a normal distribution. Indeed, we have: W.Stat $=0.98444$ and Prob $>W=0.64107$. The Breusch-Pagan residuals homoscedasticity test (table 6) leads to Chi2 $(1)=0.01$ and $\mathrm{Prob}>\mathrm{chi} 2=0.9138$. Then we proceed to analysis of the model (1) estimation. After retaining a fixed effect model, estimation of equation (1) leads to results in table 7.

We note that the econometric estimation has good statistical properties. The coefficient of determination has a strong explanatory power $\left(\mathrm{R}^{2}=0.91\right)$. Furthermore, the results show that in CAMEU zone, most of the explanatory variables have expected signs. Indeed, the level of capital and the size have a positive a significantly impact on the supply of credit for small medium enterprises. This means that an increase of one unit in the level of capital and the size of banks led to an increase in the supply of credit for small medium enterprises respectively for $27.15 \%$ and $185.01 \%$. This result refers to the intuition that an increase in the capital following the process of mergers and acquisitions of banks led to an increase in the supply of credit for small medium enterprises.

Regarding the variable size, it appears that the more it is, the more availability of credit increases. According to [7] this variable determines ability to monitor and analyze projects financed by banks. Therefore, banks will apply less credit rationing.

Concerning the liquidity variable, the econometric estimation shows that it has a negative and significant impact on availability of credit for small medium businesses in the CAMEU countries. Specifically, an increase in liquidity from $1 \%$ leads to a decrease of $34,82 \%$ in credit supply. Moreover, the negative sign of the coefficient of liquidity seems to reflect some banks caution probably due to the high potential default risk in the CAMEU countries. This result suggests that the CAMEU banks fail to turn surplus cash into profitable assets. It suggests that the more banks take risk in granting more loans, the more profitability increases. Therefore, the CAMEU banking system should grant more loans to small medium enterprises to solve the excess liquidity problem.

\section{Conclusion}

In this study we sought to assess the impact of bank consolidation on credit availability for small medium enterprises in the CAMEU zone. Our approach is based on a panel data analysis covering the period 1990-2010. It shows that banking capital, banking liquidity and banking size influence the level of small medium businesses credit availability. Like [21], our results do not confirm the literature common assumption according to which banking consolidation reduces access to credit for small medium enterprises. In this regard, for policy, we suggest continuing process of banking consolidation in the CAMEU zone in order to minimize credit rationing for small medium enterprises. Finally, in a future research, the recovery of this analysis in a dynamic framework should help to refine the understanding of bank consolidation effects on access to credit for SME.

\section{References}

[1] Avery, R.B. and Samolyk, K.A., "Bank consolidation and the provision of banking services: The case of small commercial loans", Federal Deposit Insurance Company Working Paper, 2000-01.

[2] Avom, D. and Eyeffa Ekomo M., "Quinze ans de restructuration bancaire dans la CEMAC : qu'avons-nous appris ? ", Revue d'économie financière, vol. 2, 2007, pp. 35-48.

[3] Beck, T. and Levine, R., "Bank Concentration and Crises", Mimeo, World Bank and University of Minnesota, 2002.

[4] Beck, T., Demirguc,-Kunt, A. and Maksimovic, V., "Bank competition, financing obstacles and access to credit", World Bank Policy Research Working Paper, 2003, No. 3.

[5] Beck, T., and Levine, L., "Institution building and growth in transition economies", Journal of Economic Growth, vol. 11, 2006, pp. 157-186.

[6] Bekolo-Ebe B., "La restructuration bancaire en zone franc face au défi de la mondialisation", in La mondialisation et l'économie camerounaise, (sous dir. Touna Mama), Friedrich Ebert Stiftung, 1998. 
[7] Berger, A., Miller, N.H., Petersen, M.A., Rajan, R. and Stein, J.C., "Does Function Follow Organizational Form? Evidence from the Lending Practices of Large and Small Banks", NBER working paper, 8752, 2002.

[8] Berger, A.N., Demsetz, R. S., and Strahan, P. E., "The consolidation of the financial services industry: Causes, consequences, and implications for the future", Journal of Banking \& Finance, vol. 23, 1999, pp. 135-194.

[9] Bonaccorsi di Patti, E. and Gobbi, G., "The Effects of Bank Consolidation and Market Entry on Small Business Lending". Bancad'ItaliaTemi di discussion No. 404, 2001.

[10] Bonaccorsi di Patti, E. and Gobbi, G., "Winners or losers? The effects of banking consolidation on corporate borrowers", Journal of Finance, vol. 62, 2007, pp. 669-695.

[11] Cerasi, V. and Daltung, S., "The Optimal Size of a Bank: Costs and Benefits of Diversification", European Economic Review, vol. 44, 2000, pp. 1701-26.

[12] Diamond, D., "Financial Intermediation and Delegated Monitoring”, Review of Economic Studies, vol. 51, pp. 393-414.

[13] Dietsch, M., "Financing Small Businesses in France", EIB Papers, No. 8, 2003.

[14] Fouda Owoundi, J.P., " La surliquidité bancaire dans une économie d'endettement : comment expliquer le paradoxe de la zone CEMAC“, Working Papers, 2005, Université de Yaoundé II-Soa.

[15] Hellmann, T., Murdock, K. and Stiglitz, J.E., "Liberalization, Moral Hazard in Banking, and Prudential Regulation: Are Capital Requirements Enough?" American Economic Review, vol. 90, 2000, pp. 147-65.

[16] Sapienza P., "The effects of banking mergers on loan contracts", Journal of Finance, vol. 57, n 1, 2002, pp. 329-367.

[17] Stein, J.C., "Information Production and Capital Allocation: Decentralized Vs. Hierarchical Firms", Journal of Finance, vol. 57, No 5, 2002, pp. 1891-921.

[18] Strahan, P. E. and Weston J.P., "Small Business Lending and Bank Consolidation: Is there cause for concern?", Federal Reserve Bank of New York : Current Issues in Economics and Finance, vol. 2, No. 3, 1996.

[19] Touna Mama, "La politique de crédit et le financement du développement au Cameroun", in Bekolo-Ebe, B. (sous la direction de) (2002), intermédiation financière et financement du développement en Afrique.

[20] Walkner, C., and Raes, J.P., "Integration and Consolidation in EU banking : an unfinished business", European Economy, Economic Papers, No. 226.

[21] Walraven, N., "Small business lending by banks involved in mergers", Finance and Discussion Series 97-25, Federal Reserve Board, Washington, DC.

\section{Appendices}

Table 1: Homogeneity test

\begin{tabular}{lll}
\hline Test & $\mathrm{F}(12,54)$ & Prob> F \\
\hline F test that all u_i=0: & 4.11 & 0.0031 \\
\hline
\end{tabular}

Table 2: Breusch-Pagan test (random effects)

\begin{tabular}{lll}
\hline Test & chi2(1) & Prob> chi2 \\
\hline T est $\operatorname{Var}(\mathrm{u})=0$ & 8.76 & 0.0031 \\
\hline
\end{tabular}

Table 3: Hausman test

\begin{tabular}{lll}
\hline Test & chi2(13) & Prob> chi2 \\
\hline Ho: difference in coefficients & 0,21 & 0,9998 \\
\hline not systematic & &
\end{tabular}

Table 4: autocorrelation test

\begin{tabular}{lll}
\hline Test & $\mathrm{F}(12,48)$ & Prob> F \\
\hline F test that all u_i $=0:$ & 1,55 & 0,1921 \\
\hline
\end{tabular}

Table 5: Normality test of residual (Shapiro-Wilk)

\begin{tabular}{lll}
\hline Test & W & Prob> W \\
\hline Shapiro-Wilk & 0,9844 & 0,64107 \\
\hline W test for normal data & & \\
\hline
\end{tabular}


Table 6: Homoscedasticity test for residuals

\begin{tabular}{lll}
\hline Test name & chi2(1) & Prob>chi2 \\
\hline Ho: Constant variance & 0,01 & 0.9138 \\
\hline Variables: fitted values of lnce & & \\
\hline
\end{tabular}

Table 7: Fixed effects model estimates

\begin{tabular}{lcccccc}
\hline lnce & Coef. & Std. Err. & $\mathrm{t}$ & $\mathrm{P}>|\mathrm{t}|$ & [95\% Conf. Interval] \\
\hline lnroe & -.0408037 & .0362106 & -1.13 & 0.265 & -.1134017 & .0317942 \\
lnlq & -.3482884 & .1392772 & -2.50 & 0.015 & -.627522 & -.0690544 \\
lnpm & -.1591069 & .1542835 & -1.03 & 0.307 & -.4684266 & .1502129 \\
lncap & .2715331 & .1126753 & 2.41 & 0.019 & .0456328 & .4974334 \\
cons & .8461731 & .8586018 & 0.99 & 0.329 & -.8752198 & 2.567566 \\
\hline
\end{tabular}

